\title{
EARLIEST CASES OF JUDICIAL REVIEW OF STATE LEGISLATION BY FEDERAL COURTS
}

\author{
Charees Warren
}

During the past thirty years, and especially in the last decade, there has been widespread discussion of that function of the Courts which has been concisely termed "judicial review," embracing their general authority to pass upon the constitutionality of State statutes and of Acts of Congress. In this discussion, there has frequently been too little appreciation of the fact that the power of the United States Supreme Court and of inferior Federal Courts to determine whether the action of a State Legislature has been inconsistent with the provisions of the Federal Constitution, and the power to set aside the action of a coördinate branch of the Federal Government are separate and distinct powers, proceeding from separate and distinct sources in the Constitution, and supportable on separate and distinct grounds. The one may be firmly established, without controverting in any way the arguments of those who challenge or deplore the other. Both jurists and the historians agree that the existence of the former power has been absolutely necessary for the preservation of the supremacy of the Federal Government; while, on the other hand, it is possible that the Federal Government might have functioned (though in somewhat lame manner), without the exercise of the latter power by the Courts. ${ }^{1}$

In spite of its firm legal foundation, nevertheless, the exercise of judicial review by the United States Courts with reference to State statutes was the subject of heated attack by the adherents of State-Rights, for a long period of years, and especially from I8I6 to 1858 . This opposition, however, did not arise until the lapse of twenty-five years from the date of the institution of the Federal judicial system. ${ }^{2}$ Hitherto, legal writers have very generally asserted that the earliest instance of a Federal Court decision holding a State statute invalid was Van Horne's Lessee v. Dorrance, ${ }^{3}$ in I795, by Judge William Paterson, sitting in the United States Circuit Court in Pennsylvania. From an examination of the newspapers of the last decade of the eighteenth century, however, made by the author of this article in the course of a study of the history of the Federal Judiciary, it appears that three years before the Dorrance Case, and as early as I792, a United States Circuit Court in Rhode Island held a statute of that State invalid, as an impairment of obligation of contract, and the question of the validity of the Rhode Island legal-

${ }^{1}$ See address before the Harvard Law School Association, Feb. 15, 1913, Speeches of Oliver Wendell Holmes (I913): "The United States would not come to an end if we lost our power to declare an Act of Congress void. . . . I do think the Union would be imperilled if we could not make that declaration as to the laws of the several States."

"Charles Warren, The Supreme Court in United States History (I922).

${ }^{3} 2$ Dall. 304. 
tender laws was also involved in cases in the same Court in I79I and I792. Moreover, this exercise of judicial review passed unchallenged in the very State which, only five years before, had attempted to remove its State Court Judges for holding a State law unconstitutional, in the famous case of Trevett $v$. Weeden. ${ }^{3 a}$ It is interesting, therefore, to examine more closely the conditions under which this first case arose, in I792.

The Revolutionary War was, in general, a period of prosperity for the merchants of Rhode Island, but of adversity and increase of debt for the farming and the land-owning classes and for the State itself. At the end of the war, "there was little money in the country, the lands and stock of the farmers were being seized and sold at forced sale at a great loss, silver could not be hired on the best security and distress was everywhere."4 Litigation arose on all sides, and the lawyers thrived. The paper money which had been issued by the State during the War had depreciated so rapidly that, in October, I78I, it was declared by the Legislature no longer legal tender in payment of taxes or of debts to the State. For five years, conditions grew steadily worse. Finally, in May, $x 786$, the Legislature, at the instance of the farmers and over the protest of the deputies from the commercial city of Providence, enacted a radical statute, which provided as follows:

"Whereas from a variety of causes, political and mercantile, the currency of this State now in circulation has become altogether insufficient in point of quantity for the purposes of trade and commerce, and for paying the just debts of the inhabitants thereof ; therefore to establish a circulating medium upon the firmest and most equitable principles that may be, and for facilitating this interchange of property, so essential to a commercial State and a people circumstanced as are the inhabitants of this State, be it enacted .... that One Hundred Thousand Pounds, lawful money, be forthwith emitted in bills of paper and loaned on the credit of clear landed real estates double the value of the said bills so loaned to be pledged on such real estate."

It further provided that the bills when emitted should be accepted on a par with silver and gold, estimating an ounce of coined silver at six shillings and eight pence, and should "be a.good and lawful tender for the complete payment and final discharge of all debts now due and contracted and that may hereafter become due and be contracted and for the final and full discharge of all fines and forfeitures, judgments and executions, now had, become due and recovered, of every and any nature and kind whatsoever within this State"; and that, in case of the refusal of a creditor to take these bills in payment, the debtor might apply to a Judge of the Superior Court for a citation, and might lodge the amount of his debt with the Judge, who should give a certificate, said lodgment to be deemed a sufficient tender for every purpose

\footnotetext{
3a (I786, R. I.) 2 Chandler, Am. Crininal Trials, 269.

${ }^{4}$ See in general Frank Greene Bates, Rhode Island and the Formation of the Union (1898) ro7 et seq., 124 et seq.; United States. Chronicle (Prov.) May II, I786; William R. Staples, Annals of the Town of Providence (1843) 294 et seq.
} 
mentioned in the Act; and that the Judge, in case of continued refusal of the creditor to accept the bills lodged in his hands, should, at the expiration of three months, deposit them in the General Treasury. At the same session of the Legislature in May, I786, another statute was passed, of an even more stringent nature, providing that debts due to certain corporations should not be paid by the debtors unless sued therefor, and then be paid only in legal tender : 5

"Whereas there are divers corporate bodies within this State, which have been incorporated for beneficial, charitable and religious uses who are possessed of funds for carrying the same into execution, who have lent their money upon a moderate interest to those that have had occasion to borrow, and do not wish to receive the same, unless their institutions have a use for it,- It is therefore voted and resolved, that gold, silver, or any other species of money shall not be tendered unto any such corporate body in discharge of money lent or due, unless the person or persons who borrowed or owe the same be sued, in which case any money being a legal tender shall discharge the debt, in the same manner as debts are to be discharged between individuals."

As soon as these statutes were enacted, the value of the paper money rapidly declined; creditors declined to receive it; merchants declined. to sell goods for payment in paper, and trade practically ceased. ${ }^{b}$ It soon became evident that, to enforce the laws, it was necessary to put teeth in them; and accordingly, in June, I786, another statute was passed, imposing a fine of one hundred pounds upon any man refusing to accept the paper bills in payment of a debt, or making a distinction in value between them and specie, and for a second offence a fine and incapacity to vote or hold office. ${ }^{7}$ The reasons for this Act were quaintly set forth in a recital clause as follows:

"Whereas it is highly necessary and of the last and most important consequence to the government of all States, that the proceedings of the Legislature be held in high estimation, and the most sacred regard; and that the law when promulgated be strictly adhered to, and punctually and most religiously obeyed. And whereas it is of the greatest moment, that the aforesaid emission of One Hundred Thousand Pounds, which will have the greatest tendency of anything within the wisdom of this Legislature to quiet the minds and to alleviate the distressed situation and circumstances of the good citizens of this State, should be kept in

${ }^{5}$ Records of the State of Rhode Island and Providence Plantations in New England ( 1865 ) X, I99.

${ }^{6}$ Frank Greene Bates, op. cit. 124-125; United States Chronicle, July 6, 13, 1786.

' See The Case, Trevett against Weeden on information and Complaint, for refusing Paper Bills in payment for Butcher's Meat in Market, at Par with Specie, Tried before the Honorable Superior Court in the Connty of Newport, September Term 1786, also The Case of the Judges of said Court, before the Honorable General Assembly, at Providence, October Session, I786, on Citation, for Dismissing said Complaint, Wherein the Rights of the People to Trial by $J_{u r y}$, etc., are stated and maintained, and the Legislative, $J_{u d i c i a r y}$ and Executive Powers of Government Examined and Defined, by James M. Varnum, Esq., MajorGeneral of the State of Rhode Island, etc., Counsellor at Law, and Member of Congress for said State (Providence; Printed by John Carter, 1787), at page 57. 
good credit; and that the same should be a currency equal in value to coined gold and silver; And Whereas various attempts have been made by a certain class of men, who, from mistaken principles, suppose the said currency to be injurious to their interest, and from an inclination to render invalid such laws and regulations of this Assembly, as may not quadrate with their interest, judgment and opinion of things, and for many other causes, which, if permitted to exist, will support a power in this State counter to the authority chosen and appointed by the suffrages of the free people thereof, and subversive of these laws and principles upon which the happiness, welfare and safety, of the people depends."

Two months later, still further legislation was found necessary, and at a specially called session of the General Assembly, the Act of August 22, I786 was passed, the preamble of which recited:

"Whereas, it is an established maxim in legislation, and ought to be strictly and most punctually adhered to in all wise governments, that process upon the breach of penal laws be immediate, and the penalty be inflicted or exacted directly consequent upon conviction; and whereas, the usual and stated methods and times of holding Courts within this State are impracticable, inexpedient and inapplicable to the true intent and meaning of the said Act, and altogether insufficient to carry into effect the good purposes of this Legislature touching the same."

The Act itself provided that in case of violation of the previous statutes, an information might be issued by a Judge of the Supreme Court of Judicature or of the inferior Court of Common Pleas and that a trial might be had before a Court of at least three Judges without a jury and without appeal, the Court to be convened within three days, and in said process "no essoin, protection privilege or injunction shall be in any wise prayed, granted or allowed." By another Act in August, 1786, the Legislature even went so far as to make the paper money legal tender in payment of. Continental taxes.

A period of absolute commercial stagnation ensued. Merchants closed their stores, and it was with difficulty that provisions could be obtained; many people removed from the State; few farmers from the neighboring States could be induced to bring their produce into Rhode Island. ${ }^{8}$ The scale of depreciation of the paper money as fixed by the General Assembly was as follows: in July, I786, 6 shillings in specie to 9 in bills; in October, 1786,6 to 18 ; in January, 1787,6 to 24 ; in April, I787, 6 to 34 .

Meanwhile the validity of the Act of August 22, 1786, authorizing trial before three Judges specially convened and sitting without a jury was challenged, within a month after its passage, in one of the historic cases in American legal annals. This was an information brought by one John Trevett against John Weeden, a butcher, before Paul Mumford, Chief Justice of the Superior Court, for refusing to accept paper money in payment for meat sold in his market. The Chief Justice caused a special Court to be convened under the statute; but as

\footnotetext{
${ }^{8}$ Frank Greene Bates, op. cit. I25; Providence Gazette, July 8, 22, Aug. 5, I2, Sept. 30, Oct. $7,1786$.
} 
the Superior Court was then sitting in its regular term in Newport in September, I786, the information was "referred into the term, for consideration and final determination, by the Superior Court of Judicature, Court of Assizes and General Gaol Delivery."'

On September 25, I786, the case was argued for the plaintiff by Henry Goodwin, and for the defendant by General James Mitchell Varnum and Henry Marchant, who appeared at the instance of those interested in the issue (Weeden being excessively poor and unable to pay counsel). The counsel for the defence contended with vigor that the statute was absolutely invalid because of the lack of any provision for trial by jury, and because of its requirement of discharge of debts by forced acceptance of depreciated paper. As to the power of the Court to disregard an invalid legislative act, Varnum argued impressively, saying that he was not "capable of distinguishing between an established tyranny and that government where the Legislative makes the law and dictates to the Judges their adjudication." "Have the Judges a power to repeal, to amend, to alter laws, or to make new laws?" he asked. "God forbid! In that case, they would become Legislators. Have the Legislators power to direct the Judges how they shall determine upon the laws already made? God forbid! In that case they would become Judges. The true distinction lies in this, that the Legislative have the incontrollable power of making laws not repugnant to the Constitution; the Judiciary have the sole power of judging of those laws, and are bound to execute them, but cannot admit any act of the Legislative as law, which is against the Constitution."

The day after the argument, the decision of the Court was rendered by Judge Howell, declaring "that the information was not cognizable before them," and that the penal law was "repugnant and unconstitutional." "No reasons are given for the decision," said the local newspaper. ${ }^{10}$

The consequences of the decision were immediately felt, wrote Varnum in his pamphlet account (published in 1787 ): "The shops and stores were generally opened, and business assumed a cheerful aspect. Few were the exceptions to a general congratulation, and lavish indeed were the praises bestowed upon the Court. The dread and the idea of informations were banished together, while a most perfect confidence

'Rhode Island Historical Tracts (1880) No. 8. Some Account of the Bills of Credit or Paper Money in Rhode Island, II7 et seq.

${ }^{10}$ History of the State of Rhode Island (I860) by Samuel Greene Arnold, II, 525 et seq.; State of Rhode Island and Providence Plantations at the End of the Century (I902) by Edward Field, III, Chap. 2. "The struggle for Judicial Supremacy," Newport Mercury, Oct. 2, 1786; see Gleanings from the Judicial History of Rhode Island (I883) by Thomas Durfee, R. I. Hist. Tracts XVIII, 52. See also Irving Bedine Richman, Rhode Island a Study in Separation (1905) $80-83$, contending that the decision was one of jurisdiction only and not of constitutional law; Charles B. Elliott, The Legislatures and the Conts in Pol. Sci. Qu. (1890) 224,233 et seq. See contra references cited in footnote 9 at p. 233 of the article by Elliott. 
was placed in judicial security. The paper currency obtained a more extensive circulation, as everyone found himself at liberty to receive or refuse it. The markets which had been illy supplied, were now amply furnished, and the spirit of industry was generally diffused. Every prospect teemed with returning happiness and nothing appeared wanting to restore union and harmony among the contending parties. The demon, however, of discord was not entirely subdued; for upon the next succeeding week a summons was issued from the Rhode Island Assembly requiring an immediate attendance of the Judges before it," as follows : ${ }^{11}$

"Whereas it appears that the honorable the justices of the Superior Court of Judicature, Court of Assize, etc., at the last September Term of the said Court, in the County of Newport, have by a judgment of the said Court declared and adjudged an Act of the Supreme Legislature of this State to be unconstitutional, and so absolutely void; and whereas it is suggested that the aforesaid judgment is unprecedented in this State, and may tend directly to abolish the legislative authority thereof,-it is therefore voted and resolved that all the justices of the said Court be forthwith cited by the sheriffs of the respective counties in which they live, or may be found, to assign the reasons and grounds of the aforesaid judgment, and that the Clerk of the said Court be directed to attend this Assembly at the same time, with the records of the said Court which relate to the said judgment."

In compliance with the summons of the Assembly, three of the Judges of the Superior Court appeared, the other two being unwell. The Assembly dismissed them at that time, but directed them to appear at the October session, at which, on October 30,1786 , the three Judges (Hazard, Tillinghast, and Howell) attended and gave notice in writing to both Houses "that they waited their pleasure." Each Judge also submitted a statement of the reasons for his decision, and, as Varnum wrote: "Mr. Howell, the youngest Justice addressed himself to the Assembly in a very learned, sensible and elaborate discourse, in which he was upwards of six hours on the floor. . . To the observations of the Judges, succeeded a very serious and interesting debate among the members, wherein many arguments and observations were adduced on both sides. At length a question was taken, 'whether the Assembly was satisfied with the reasons given by the Judges in support of their judgment.' It was determined in the negative. A motion was then made, and seconded, 'for dismissing the Judges from their office.' This was coming to the point, for the obtaining of which the greatest exertions had been made. ... Upon a question of so unprecedented and so interesting a nature, many of the leading gentlemen of the

${ }^{11}$ Records of the State of Rhode Island and Providence Plantation, X. See Frank Greene Bates, op. cit. I34-I39. "The decision was hailed with joy in Providence and Newport. Business at once awoke, and for a short time paper circulated freely..... But on the part of the defeated party momentary dismay was turned to wrath against the Superior Court. The Assembly, the willing instrument of the paper money policy, was called into service." 
Administration seemed almost ready to yield the ground upon which they had contended. Some were for displacing the Judges at all events; some were for saving appearances by drawing out a concession on the part of the Court, and others were determined fully to justify them." At this juncture and during the debate, the Judges, on November 4, I786, presented a memorial demanding a hearing on "certain and specific charges" "before some proper and legal tribunal."12 Finally, the Assembly decided that, as no accusation against the Judges was formally before it, the only question for its decision was whether they should be discharged from any further attendance upon it; and it voted as follows: ${ }^{13}$

"The said three Judges being fully heard before the Assembly, it is voted and resolved, that no satisfactory reasons have been rendered by them for their judgment on the foregoing information .... and that as the Judges of the Superior Court are not charged with criminality in giving judgment upon the information they are discharged from any further attendance upon this Assembly on that account."

Meanwhile, it was evident even to their advocates that the legal tender laws were rapidly becoming unenforceable in a practical operation. A proposition of the Assembly to require every citizen to take a test oath to make every endeavor that paper money should have an equal value with specie and to sell or expose for sale no article for which he would not accept in payment either paper or gold at the same rate (all officeholders, lawyers and persons entering or clearing vessels to be obliged to subscribe to the oath under severe penalties), was rejected in October, I786, on a referendum to the voters in town meetings assembled.14 On January 6, I787, the Act of June, I786, containing the provisions for fines and penalties was repealed by the Assembly; and the original Act of May, I786, was rendered practically inoperative by the Courts, when the Superior Court adjourned its March Term in I787, for three weeks, on the ground that the depreciation of paper made the administration of justice impossible. "At the April Term in Washington County, more than twenty bills in equity were heard for the redemption of mortgages of estates. The paper for redeeming these estates was brought into Court by the sackful. Determined not to make a farce of justice, the Judges refused to record these tenders and put over all such cases until the next Term." 15

Ine copy of the printed report of this case of Trevett $v$. Weeden which belonged to David Howell is in the Library of Congress; and in Howell's handwriting, it is stated that this memorial was written by him.

${ }^{13}$ See Providence Gazette, Nov. II, I786.

"United States Chronicle, Oct. I2, I786; Providence Gazette, Oct. I4, I788; Frank Greene Bates, op. cit. I39-I4I; yet while paper money (which had then fallen from 9 to 6 to 24 to 6 ) was not in fact accepted in transactions between individuals, the Assembly by Act of January 6, 1787 , took the extraordinary step of enacting that payment of the State debt might be made in paper to the extent of one quarter. Samuel Greene Arnold, History of the State of Rhode Island (I860) 529-535.

${ }^{25}$ Frank Greene Bates, op. cit. I43-I44; Samuel Greene Arnold, op. cit. 535. 
One last effort, however, was made by the paper-money party to bolster up their pet legislation. They had tried new stringent enforcement laws and finding them useless had repealed them. They now tried a new set of Judges. As, at this time, the Judiciary were chosen annually by the Assembly, the next Assembly, controlled by the farmers, on May 2, I787, rejected for reappointment four of the five Judges who had participated in the decision of Trevett $v$. Weeden, the Chief Justice, Paul Mumford, alone being re-elected.

But neither success in the spring election nor the displacement of obnoxious Judges brought any improvement in business conditions. Economic law was stronger than popular vote or judicial decision. The value of the paper money continued to fall, from 34 to 6 in April, I787, it dropped to 38 to 6 in April, I788; to 45 to 6 in July, 1788 ; to 60 to 6 in January, 1789 ; and to 90 to 6 in July, $1789 .{ }^{16}$ Towards the end of the third year of this kind of experience, there was a political reaction in the State.

In March, 1789 , a motion in the Assembly to repeal the tender law of May, I786, was lost by a vote of I9 to 27 , and in June, a similar motion was lost by a vote of 20 to 30 ; but in September, I789, the Assembly, admitting that great injustice would result from the awful depreciation unless some action should be taken, suspended the Act until the next Session. Finally, on October 12, I789, the Act was repealed, though, with the proviso, as a sop to the debtor class, that debtors might substitute property at an appraised value for money in discharge of their liabilities, and that the time allowed for redemption of mortgaged estates should be extended from five to twelve years. ${ }^{17}$ As a factor in bringing about this decision, it may be noted that other States had begun to retaliate against Rhode Island for the wrongs caused by its paper-money legislation, and Connecticut actually excluded citizens of Rhode Island from its Courts. ${ }^{18}$

Meanwhile, the paper money issue had become somewhat involved with the issue of State-Rights and the agitation for strengthening the powers of the Federal Congress and for adopting a new Federal Constitution. The State of Rhode Island was dividing politically on these lines. Roughly speaking, the farmers, the inhabitants of country towns, and the paper-money men became Anti-Federalists; the merchants and the citizens of Providence and Newport became Federalists. The Anti-Federalist attitude of the State and its failure to ratify the Constitution were largely due to its fears as to the operation of that clause which prohibited a State from impairing the obligation of contracts.

\footnotetext{
${ }^{16}$ These figures were official, according to the scale of depreciation fixed by the General Assembly.

${ }^{27}$ Samuel Greene Arnold, op. cit. 557. In February, I793, the State began to destroy by burning such paper money as it had accumulated from payment of taxes, and up to May, $1803,96,646$ pounds were destroyed. As late as I8I9 paper was received in payment of taxes to the States at the rate of 90 to 6. Rhode Island Hist. Tracts (I880) No. 8, op. cit. II7 et seq.

${ }^{13}$ Providence Gazette, Feb. 28, 1789; Frank Greene Bates, op. cit. 185.
} 
If that provision should be held applicable to State statutes enacted before the adoption of the Constitution, then it was clear that the legaltender laws of Rhode Island would be declared unconstitutional by the Federal Courts (as they had been by the State Judges in Trevett $v$. Weeden) and Rhode Island was unwilling to take this risk. ${ }^{19}$ The repeal of its legal-tender law, however, on October 12 , I789, rendered this reason for refusal to join the Union less potent. But even when the State finally ratified the Constitution, on May 29, I790, by the close vote of 34 to 32 , it still attempted to guard itself against Federal interference with its legislation, by proposing an Amendment to the Constitution to the effect that the jurisdiction of the United States Courts should not extend to criminal prosecution by a State or to suits by any individual against a State, and that Congress should not, "directly or indirectly, either by themselves or through the Judiciary interfere with any one of the States in the redemption of paper money already emitted and now in circulation or in liquidating or discharging the public securities of any one State and that every State shall have the exclusive right of making such laws and regulations for the before mentioned purposes as they shall think proper."

Only a year after Rhode Island entered the Union, the issue which it had apprehended arose in a case in the United States Circuit Court for the District of Rhode Island, tried and decided in June, I79I, involving, (amongst other questions), the constitutionality of its legal-tender laws of May and August, I786. The case was an ejectment proceeding brought April 30, I79r, by David Leonard Barnes, of Taunton, in the State of Massachusetts, and Joseph Jenckes and others, of Providence, in the State of Rhode Island, against William West, of Scituate, in the State of Rhode Island. The facts appearing in the records were as follows: West had made a mortgage of land in 1763 for one year for the payment of 2,I74 dollars; no foreclosure having taken place, on September 12,1789 , he tendered payment of the amount due then, viz., I,593 pounds, to the owner of the mortgage; the tender, made in paper money, under the Act of May, I786, was refused by the mortgagee; whereupon, West, following the procedure prescribed by the Act of August, I786, lodged the money with a Judge of the Superior Court, who issued a citation to the mortgagee to appear within ten days from service (as directed by the statute); this citation was served on September I7; the mortgagee

${ }^{19}$ In Cooper v. Telfair (1800) 4 Dall. I4, Judge Chase raised the question whether the provision of the Federal Constitution relative to State bills of attainder applied to such bills enacted prior to 1789 . In concurring with the Court in sustaining Georgia statutes of 1782 and 1787 , he said: "There is likewise a material difference between laws passed by the individual States during the Revolution, and laws passed subsequently to the organization of the Federal Constitution. Few of the Revolutionary acts would stand the rigorous tests now applied. ... Whether the power (i. e. the power to declare acts invalid) under the existing Constitution can be employed to invalidate acts previously enacted is a very different question turning upon very different principles, and with respect to which I abstain from giving an opinion." 
failing to appear, the Judge on September 28, issued to West, the mortgagor, a certificate of compliance with the statute and a discharge of his debt. West, in defending the ejectment suit, supported his title to the mortgaged premises by a plea in bar setting up the above facts, and pleading payment of the mortgage, by virtue of his compliance with the statute under which he claimed "to have legally paid and satisfied and discharged the principal and interest." 20

The Court (consisting of Chief Justice Jay, Justice William Cushing, and District Judge Henry Marchant) decided broadly that the plea in bar was bad, without specifying any grounds for its decision as follows :21

"Whereupon all and singular the premises being seen and by the Court here fully understood, and mature deliberation being thereon had, it seems to the Court now here, that the plea in Bar of the said William West aforesaid is bad and insufficient in Law to preclude the plaintiffs from having their action aforesaid thereof against the said William West. Therefore it is considered, that the plaintiffs recover and have their seizin against the said William West of the said Farm or Tract of land with the appurtenances, and also their costs, taxed at Fourteen dollars, and eighteen cents."

The contemporary newspapers though making no reference to this particular case, stated that: "The Court, in the conduct of the business and in their decisions, gave great satisfaction. Their candour, impartiality and discernment were universally acknowledged and applauded. Justice itself seemed to preside on the bench and inspire it." ${ }^{22}$ It is evident, therefore, that this decision in Barnes v. West, though adverse to a debtor claiming under the State legal-tender law, caused no popular excitement or criticism, at the time. It may be that this was due to the fact that the Federal Court did not pass upon the constitutional question involved. The State Courts, themselves, however, were now freely holding that the Act of October 12,1789 , authorizing payment by a debtor in property at an appraised value, and similar laws were invalid,

${ }^{20} \mathrm{It}$ is interesting to note that the Federal Circuit Court might well have decided the case on a point of jurisdiction; for inasmuch as the case was brought in that Court on the ground of diverse citizenship, it appeared on the face of the record that some of the plaintiffs were citizens of the same State as the defendant, and therefore under the law (as settled by later decisions of the Supreme Court) the Court had no jurisdiction. The point apparently was not raised.

${ }^{21}$ See original records now in the files of the District Court of the United States for the District of Rhode Island-Barnes et al. v. William West et al., June Term, I79I, United States Circuit Court, District of Rhode Island.

"Boston Gazette, July 4, I791; Massachusetts Spy, July I4, I79I. The Columbian Centinel (Boston) June 29, I79I, stated that on June 23 the Circuit Court adjourned "after a session of fifteen days during which a variety of civil causes were heard and determined."

James'Iredell, a Justice of the Supreme Court of the United States, wrote to Rev. A. Iredell, November 30, I792: "The people are strongly and zealously attached to the government of the United States; even Rhode Island itself, which State, I am told, has been principally brought over to a degree of content by the decisions and manner of doing business of the Courts of the United States, is in 
and these decisions aroused no opposition. ${ }^{23}$ Moreover-a fact still more remarkable- the State Legislature itself substantially acquiesced in the right of the Judiciary to hold its statutes invalid; for at the very time of the decision by the Federal Court in Barnes v. West, the Legislature took the following action on a State Court decision (as described by a Providence newspaper): "An action at a special Court having been commenced in the County of Bristol against the Sheriff of the County of Providence for having received the paper money of this State at the rate of fifteen for one, agreeably to the Act passed before the adoption of the National Constitution called the Substitute Act, wherein judgment was given by the unanimous opinion of the Court against the Sheriff on the principle that by the adoption of the Constitution that Act was virtually repealed, a petition was therefore presented for the interposition of the Legislature; but as the House of Representatives refused to receive the petition, it must be inferred as the sense of the Legislature that the Act before mentioned was superseded, by the adoption of the Constitution and that it has thereby become null and void, consequently nothing but silver and gold can now be a Tender in this State on judgments obtained for money."

This acquiescence by the Legislature in the legal proposition that a State law, enacted prior to the adoption of the Constitution, of a nature forbidden to a State by the provisions of the Constitution was to be considered invalidated, is a striking illustration of the complete submission of the State to the Federal authority, within only fourteen months after its tardy ratification of the Constitution.

Two months later, it seemed likely that the question of the constitutional validity of the State legal tender law would be passed upon by the Supreme Court of the United States; for the case of West $v$. Barnes had been taken up to that Court on writ of error, and was on its docket at the Term held in August, I79x. But, on being called for argument on the second day of the Term, David L. Barnes of Massachusetts, one of the defendants in error and Counsellor of the Court (just admitted) rose and stated to the Court that the proceedings in the above cause could not be properly before the Court, the writ of error having issued from the office of the Clerk of the Circuit Court and not from the office of the Clerk of the Supreme Court. ${ }^{25}$ On this point of procedure, the

every respect infinitely better than it was." Griffith J. McRee, Life and Correspondence of Jantes Iredell ( 1858 ).

${ }^{23}$ See Providence Gazette, June 25, I79r: "The Court of Common Pleas in the County of Washington at a late Term, gave their unanimous judgment that nothing but silver or gold is a tender to discharge execution. The same judgment has also been given at a late special Court of Common Pleas in the County of Bristol on the same question. In consequence of which it is said, that no Sheriff in the - State presumes to receive anything but hard money in discharge of executions."

"4 Providence Gazette, July 9, I791.

${ }^{25}$ See account given in Dunlap's American Daily Advertiser, Aug. 13, I79i; Columbian Centinel, Aug. 13, I791; Massachusetts Spy, Aug. 25, 1790; this account is fuller than that given in 2 Dall. 4or. 
Court dismissed the writ of error. Had it not been for this technical blunder, it is probable that the very first case to be argued before that Court would have presented the delicate issue of the Court's power to declare the invalidity of a State statute.

On November 9, I79x, two months after the decision of the Supreme Court, Barnes brought another suit in ejectment in the Circuit Court for the District of Rhode Island, against West and several additional defendants, based on the same mortgage as the previous suit. West set up the same plea of payment. The Court (composed again of Chief Justice Jay, Justice William Cushing, and District Judge Henry Marchant), in June, I792, for a second time held the plea bad. It appears from-an account in a contemporary newspaper that though many other points were involved in the case (including undoubtedly the question of the constitutionality of the law), the Court did not pass upon them. The Providence Gazette described the decision as follows: "In the cause of Barnes and others against West and others upon a mortgage, the Circuit Court at Newport gave their opinions on Wednesday last (June I3) unanimously in favour of the plaintiffs. They, however, decided one point only. In this case, the money was lodged with the Justice on the I6th of September and the operation of the emitting Act as it is called was suspended on the Igth of the same month. The Court were therefore clearly of opinion that, as the person to whom the money was tendered was to have ten days to receive it of the Justice, and as three days only elapsed before the Justice's power to keep the money or pay it to the creditor expired, the tender was not made conformable to the statute and therefore could have no effect. They did not give any opinion on many other points that were made in the case and which will probably come up in divers other causes now pending respecting tenders of paper money upon mortgagors."26

But while the United States Circuit Court did not pass upon the constitutional question as to impairment of obligation of contract in this case, another case which had been argued at this same June, I792, Term, presented the question in connection with another statute; and in this latter case, Alexander Champion and Thomas Dickason v. Silas Casey (which appears to have been hitherto unnoted by legal historians) the Federal Judiciary, for the first time in its history, proceeded to hold a State statute invalid. The law involved was a resolve of the General Assembly, passed in February, I79I, in response to a petition of a debtor for an extension of three years' time in which to settle his accounts with his creditors and for an exemption from all arrests and attachments for such term of three years. ${ }^{27}$

\footnotetext{
${ }^{2}$ Providence Gazette, June 16, 1792; United States Chronicle (Prov.) June I4, I792; Salem Gazette, June 26, I792.

"The petitioner, Silas Casey, represented as follows: "Your petitioner from repeated heavy losses at sea, and other unexpected disappointments in a long course of very extensive mercantile transactions finds his affairs extremely embarassed, and himself unable to do that justice to his creditors which his former prompt payments gave them reason to expect, he hath for some time past been
} 
In this suit, brought in the Federal Court, May 7, I792, by British merchants against three Rhode Island merchants on an account annexed for 19,987 dollars; the defendant Casey set up in his plea the above legislative resolve. ${ }^{28}$ The judgment of the Court was rendered at the same time as that in Barnes v. West and was to the effect that they "were of the opinion, after mature deliberation on the plea of the Defendants, that the plea of the defendants was insufficient to abate the writ of the plaintiffs." Though no grounds for its decision were given in the Court's judgment, the Rhode Island newspapers printed full accounts of the reasons given by the Court. One said: "The Court also determined in the case of Champion and Dickason against Silas Casey that the Legislature of a State have no right to make a law to exempt an individual from arrests, and his estate from attachments, for his private debts, for any term of time, it being clearly a law impairing the obligation of contracts, and therefore contrary to the Constitution of the United States." Another newspaper stated that: "The defendant's counsel pleaded a resolution of the State in bar of the action, by which he was allowed three years to pay his debts and during which he was to be free from arrests on that account. The Judges were unanimously of opinion, that, as by the Constitution of the United States, the individual States are prohibited from making laws which shall impair the obligation of contracts, and as the resolution in question, if operative, would impair the obligation of the contract in question, therefore it could not be admitted to bar the action." 29

Though this decision was given great publicity in the newspapers throughout the States, it seems to have aroused no opposition to the Federal Courts, and not only was there no public challenge of the deci-

arranging his books and papers and preparing them for a settlement, but he finds his accounts so extensive and his credits so peculiarly situated that it will require great attention, application and time to bring them to a close with advantage to himself and creditors, be impossible ever to complete that object, while he is subject to the demands which an apprehension of a change in his circumstances naturally urge unless therefore he can obtain indulgence from your Honors to attend the settlement of his accounts without interruption, himself and family will not only be greatly distressed, but his Creditors loose many advantages which such an opportunity would afford, he therefore most respectfully solicits the interposition of this Honorable Assembly, and that they would extend to him the term of three years for the above purpose, and that in the meantime he be exempted from all arrests and attachments." On this petition, the Legislature had passed a Resolve as follows: "It is voted and resolved that the prayer of this petition be and the same is hereby granted."

${ }^{2}$ See original record in Champion and others $v$. Silas Casey and others, November Term 1792, United States Circuit Court District of Rhode Island, now in the files of United States District Court for the District of Rhode Island.

${ }^{20}$ For these reports of the decision, see Columbian Centinel, June 20, 1792; Providence Gazette, June I6, 1792; United States Chronicle (Prov.) June I4, I792; Salem Gazette (Mass.) June 26, 1792; New York Daily Advertiser, June 22, 1792; Connecticut Journal, June 22, I792; and see many other newspapers of that date. 
sion but it was explicitly accepted by the Rhode Island Legislature, whose acquiescence was expressed formally (as described by contemporary papers) as follows: "In conformity to a decision of the Circuit Court, the Lower House of Assembly voted on Wednesday that they would not grant to any individual an exemption from arrests and attachments for his private debts, for any term of time." 30

It thus appears that though, thirty years later, the right of the Federal Courts to declare a State statute to be invalid was hotly attacked by State after State in the Union, the exercise of this right, in I792, was accepted without protest, even in the very State which, five years earlier, had sought to impeach its State Judges for exercising the same right.

The episode is illuminating on the question of this alleged "usurped" power of the Courts. A careful study of the history of the periods from $I 789$ to $I 8 x 9$, from 1845 to $I 860$, and from $I 865$ to $I 87 x$, will show that each political party, Federalist and Anti-Federalist, Democrat and Whig, Democrat and Republican, upheld the power of the Court, when the Court's decision, whether in favor of or against the validity of the statute, coincided with the political views of that party on the question involved in the case; and each challenged the Court's power on many occasions when its decision was contrary to those political views. In other words, opposition to the right of judicial review was not a judicial or constitutional doctrine or political tenet consistently maintained by any particular party; it was purely an opportunist, partisan manoeuvre, which each political party was willing to advocate and employ to serve its political ends.

\footnotetext{
${ }^{30}$ One month before this decision, the Federal Circuit Court sitting in Pennsylvania (Judges Wilson, Blair, and District Judge Peters) had decided a case involving the validity of a statute of that State; but had held it not violative of the Federal Constitution. See Collet v. Collet (1792) 2 Dall. 294; Gazette of the United States, May 2, I792; New York Daily Advertiser, May 2, 1792.

It is interesting to note that a similar constitutional question arose the next year, I793, in the Federal Circuit Court in Connecticut, but no decision was rendered. See Connecticut Courant, Oct. 7, I793. "The cause, which involves the question whether a protection granted by the Legislature of the State to a person who had a petition for an insolvent Act depending before them, (which protection was to continue no longer than during the session) was valid and sufficient to protect his person from an arrest by process or execution from the Courts of the United States, was fully debated upon demurrer, but is continued. . . . This cause involves consequences of immense magnitude, and we trust will not be decided without full deliberation." This case has not hitherto been noted.
} 